This PDF is a simplified version of the original article published in Internet Archaeology. Enlarged images which support this publication can be found in the original version online. All links also go to the online version.

\title{
Curation of Digital Archaeological Data in Norway
}

Mieko Matsumoto and Espen Uleberg

Archaeological documentation from surveys and excavations in Norway are created by a limited number of actors. Excavations are mainly carried out by the five university museums. NIKU (Norwegian Institute for Cultural Research) is responsible for excavations of medieval cities and churches. Maritime museums excavate in lakes, rivers, and below past and present sea level. Archaeological surveys are mainly the responsibility of the counties.

Riksantikvaren (Directorate of National Heritage) is responsible for the national Historic Environment Records (HER), Askeladden, which offers the possibility to upload or insert links to reports from archaeological investigations. Riksantikvaren also archives excavation documentation from churches and medieval cities. The Norwegian university museums have, since the 1990s, cooperated on digitising a national repository and making the collections available online. Presently there are also repositories at the maritime museums, Riksantikvaren and the counties. The infrastructure ADED (Archaeological Digital Excavation Documentation) is a repository for detailed excavation documentation, and the BItFROST infrastructure project contributes to better storage and availability of 3D data. Future development will be more complete national databases, and towards closer international cooperation, creating better integration and availability of several repositories. 


\section{Introduction: the Data Flow Structure}

Archaeological surveys and excavations in Norway are carried out by a restricted number of actors, comprising the university museums (Figure 1), maritime museums, the counties, and NIKU (Norwegian Institute for Cultural Research). Documentation is stored at the museums, counties, and Riksantikvaren (Directorate for National Heritage). The relatively few agents and long tradition of cooperation creates a favourable environment for defining repositories and giving common access to archaeological data. The Museum of Cultural History (KHM) in Oslo represents a good example to illustrate the flow of data and objects, the structure of the archiving workflow, and the interaction between different organisations and their responsibilities (Figure 2). Further details of this process are presented below.

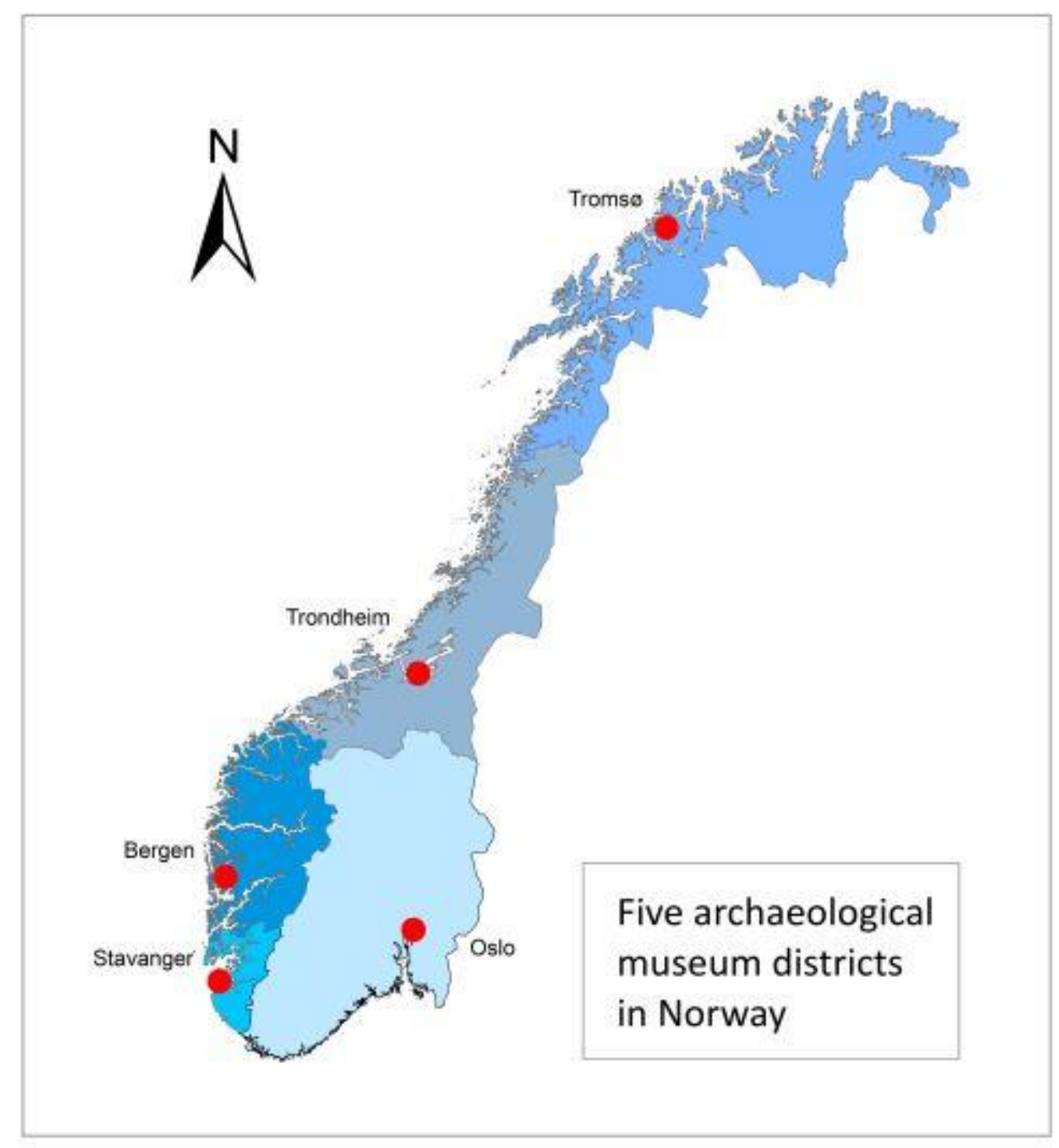

Figure 1: The five cities with university museums and their museum districts. Museum of Cultural History, University of Oslo; Archaeological museum, University of Stavanger; University Museum, University of Bergen; NTNU University Museum, Trondheim; The Arctic University Museum of Norway, Tromsø. 
The Norwegian act concerning cultural heritage automatically protects sites and artefacts older than the reformation (1537), standing buildings older than 1649, coins older than 1650, and Saami sites dating before 1917. Artefacts and coins belong to the state, and the university and maritime museums are responsible for curating this material.

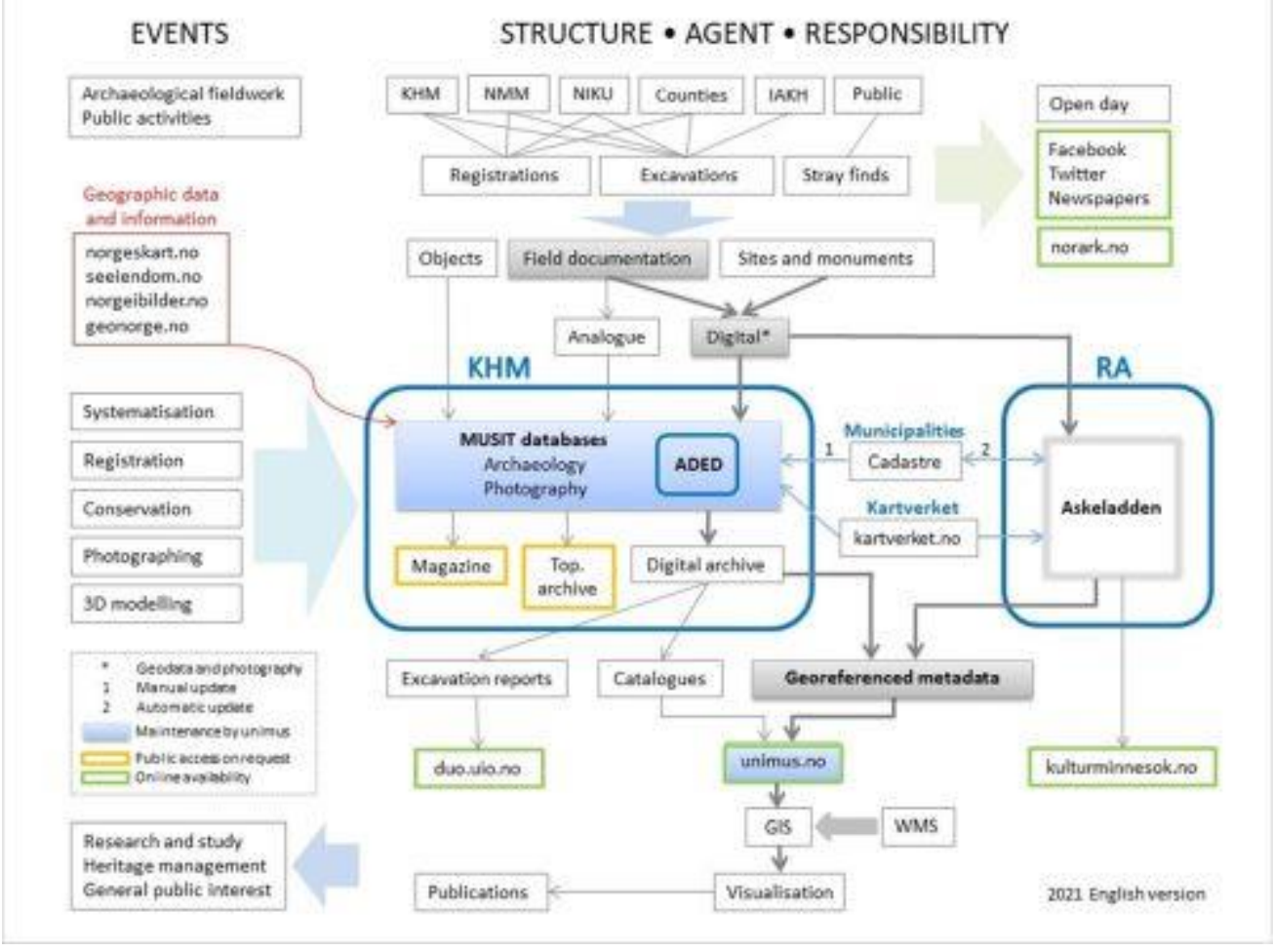

Figure 2: The structure, agents, and responsibilities in the creation and curation of excavation data within KHM's museum district. KHM: Museum of Cultural History, NMM: Norwegian Maritime Museum, NIKU: Norwegian Institute for Cultural Research, IAKH: Department of Archaeology, Conservation and History, University of Oslo, MUSIT: the IT cooperation among Norwegian university museums (2007-2021), ADED: an infrastructure for Archaeological Digital Excavation Documentation, RA: Directorate of National Heritage, Askeladden: the national Heritage Environment Register, duo.uio.no: the Research Archive of the University of Oslo, unimus.no: cooperation among Norwegian university museums since 2021.

\section{Agents and Responsibilities}

Five university museums, in Oslo, Stavanger, Bergen, Trondheim, and Tromsø, perform most of the excavations in Norway. Each of them is responsible for a defined geographical area (Figure 1), and are repositories and public archives for archaeological documentation within their districts. The Norwegian university museums have a long history of national cooperation to make archaeological information digitally available. The Documentation Project from the early 1990 s was followed by the Museum Project (1999-2006) and MUSIT (2007-2021). One of the important outcomes which should be mentioned is the MUSIT database in archaeology (MUSITark), used by the university museums. MUSIT ended in 2021 
but the university museums with cultural historical collections continue to cooperate in UniMus:Kultur.

Maritime and marine archaeology are part of the university museums in Tromsø and Trondheim, while there are separate maritime museums in Oslo, Stavanger, and Bergen. The Norwegian Maritime Museum (NMM) in Oslo excavates areas that are below medieval sea level in medieval Oslo. This creates the situation that archaeological material from neighbouring areas in central Oslo can be stored in separate systems and different institutions according to whether the site is defined as below or above this elevation.

NIKU is responsible for excavations in the medieval cities and churches. They use the MUSITark database and transfer all objects and documentation to the university museums. NIKU is also the foremost contributor to georadar surveys within archaeology in Norway (Gustavsen et al. 2013).

The counties are mainly responsible for archaeological surveys, but conduct some minor excavations in connection with surveys. They enter results from the surveys into the HER Askeladden, and submit artefacts and reports to the university museums. The counties also have a role in transferring stray finds made by the public to the university museums.

The archaeological university institutes are responsible for only a few excavations in Norway, mainly for educational purposes. They get access to MUSITark in the same way as NIKU, and transfer artefacts, reports and other field documentation to the university museums.

The public is obliged to submit archaeological finds to the university museums via the counties. The finds - stray finds and from metal detectorists - are registered in MUSITark along with all other archaeological and numismatic finds.

\section{Developing the System}

Digitisation started early in the 1990s with the Documentation Project (1991-1997) (Holmen and Uleberg 1996; Aukrust and Hodne 1998). It was a joint venture among the faculties of humanities at the Norwegian universities. The main goal was to digitise archives at several university institutes and make them available for research and the general public, as part of democratising knowledge (Uleberg and Matsumoto 2019). For archaeology, artefact catalogues, images, and topographic archives were digitised. The subsequent Museum Project (1998-2006) (Ore and Rangsæeter 2007) not only continued the work at the museums, including the natural history collections at the university museums, but also started to develop common database solutions. MUSIT (2007-2021) completed the first stage of this database solution - MUSITark - which allowed an innovative online publication. The present UniMus:Kultur cooperation concentrates on the second phase, under the name of the UniMus database, which is intended to aid in collection management for ethnography, and numismatics, as well as archaeology. 
The MUSITark and UniMus database are developed and maintained by the Department for Data Capture and Collections Management (DS), part of the University Centre for Information Technology (USIT) at the University of Oslo. USIT's DS group is also responsible for the university museums' common repository. The collections are published as open data as downloadable datasets and APIs at the UniMus website, Unimusportalen.

\section{Archaeological Collections}

All artefacts in the university museums' collections are registered in MUSITark (Uleberg and Matsumoto 2010; Matsumoto and Uleberg 2015), whether they are from excavations, metal detecting or simply stray finds. The cumulative curve showing the growing number of finds in the collection at KHM is a good indication of the increasing archaeological activity in the 1870-1880s and after 2000 (Figure 3). Each find is given a museum number as the object's permanent ID, and can consist of one or several thousand artefacts from the same site and period. In this way the finds reflect the increasing activities - both in the number of excavations and stray finds submitted by the public. The increasing amount of available information demonstrates the growing need for structured digital repositories. The new UniMus database will be the current solution for old challenges, and it will provide all entries with a global URI. At present, more than 1.5 million objects, most of them georeferenced, can be found at the Unimusportalen.

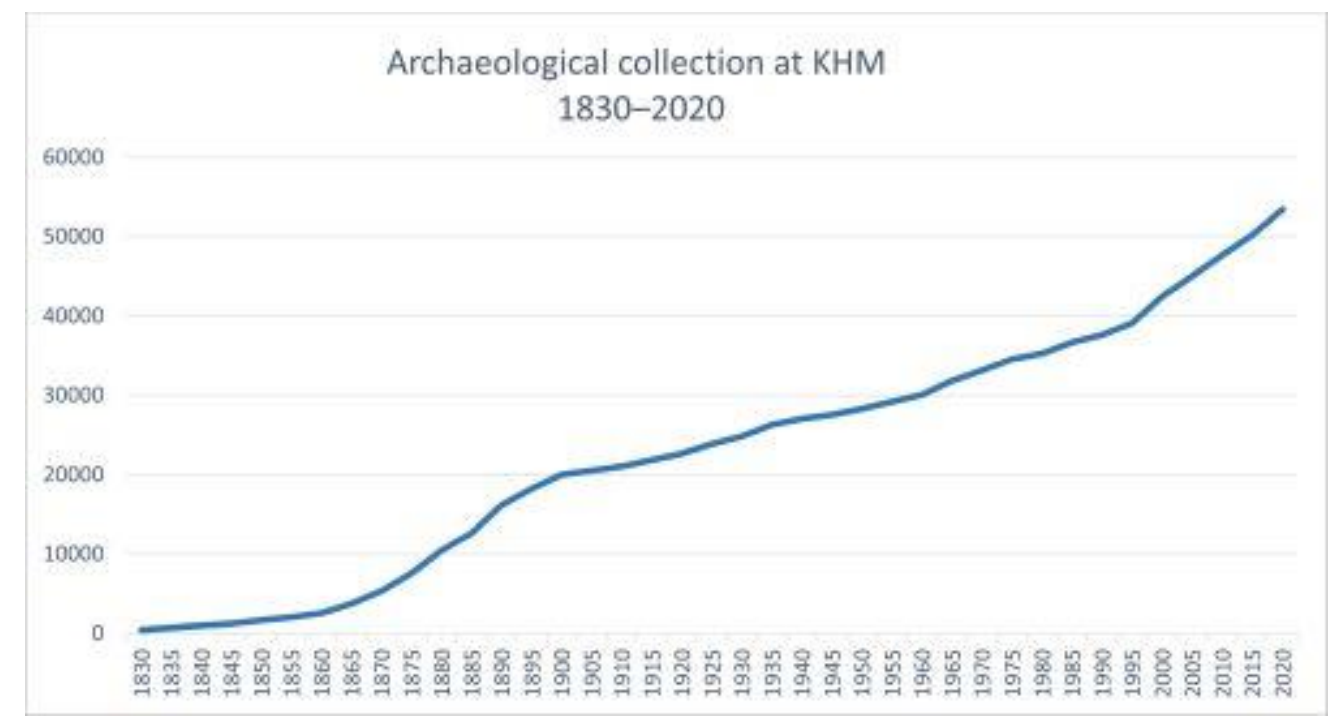

Figure 3: Cumulative curve for the archaeological collection development at the Museum of Cultural History, University of Oslo. Until 1900 each artefact was given a separate museum number. After this year a group of objects with the same provenience (location and period) is assigned one museum number. There can be from one to several thousand objects under the one and same number. The steep increase in the 1870-1880s reflects the period of grave mound excavations. The second steep increase after 2000 reflects the present increase of archaeological information, both from large excavations and metal detector activity.

\section{Excavation Documentation}


Digital documentation of excavations was used at a few larger projects in Norway from the 1990s, and at a wider scale from the 2000s. PenMap and ArcGIS were used at some excavations, and the Swedish Intrasis was first used at the Kaupang excavations (2000-2003) (Kristensen 2004). Through the MUSIT cooperation, the university museums discussed documentation standards, and decided to define and use a specific Intrasis template from 2011. In the following years, each museum stored the Intrasis files at their own servers. However, the agreement on standards had raised the possibility for merging and shared access to these data, and this was the background for the three-year ADED project (Archaeological Digital Excavation Documentation) starting in 2018 (Ore and Uleberg 2019). ADED is an infrastructure project financed by the Norwegian Research Council, and the project partners are obliged to uphold it for at least five years, from 2021 on. ADED's main function is twofold: to develop a common repository for excavation data, and to provide a freely accessible interface where anyone can query and download data across all excavation projects.

The 750 Intrasis files included in this establishing phase of the infrastructure will be available in ADED in 2022. In the coming years, uploading new projects will be routine. Documentation from NIKU and the counties, as well as older digital documentation in other formats, will be uploaded continuously, and analogue excavation documentation will be digitised. In this way, ADED, with links to Unimusportalen, will be a hub for archaeological research and studies.

NMM, Stavanger Maritime Museum, and Bergen Maritime Museum ran the project «Fra felt til Fil til Folk» (From Field to File to Public) in 2019-2021 that will make their digital excavation documentation available online for the general public. Their repository is at KulturlT, which offers services to a range of museums in Norway and Sweden.

\section{Norwegian HER — Askeladden}

The counties, NIKU, and the maritime museums update the national HER, Askeladden, with their survey results. Askeladden is also updated by the maritime and university museums and NIKU post-excavation, with information pertaining to core elements that relate to the protection of sites, like excavated areas and preservation condition. Askeladden holds information about excavated areas and the status of the site, while detailed excavation documentation (except for the maritime museums), and links to artefacts, will be stored at ADED. Excavation reports can be linked to or stored in Askeladden. The data from Askeladden will also be published with data from the Danish Fund og Fortidsminder as part of an EOSC (European Open Science Cloud) project on Nordic Archaeology. It will be beneficial to include this in wider international projects such as ARIADNEplus.

\section{Museum Archives}

Archaeological documentation, including excavation reports at the university museums, is kept in topographically ordered archives. Universitetsmuseet in Bergen 
(UM) (Engevik et al. 2004) and Vitenskapsmuseet NTNU (VM) in Trondheim have digitised their topographic archives. The data are curated as part of

the UniMus:Kultur cooperation. The museums in Oslo, Stavanger, and Tromsø have integrated their data in the university archives. Access to the material is given upon request.

$\mathrm{KHM}$ has digitised a few selected municipalities as well as one of the former ten counties in the museum district, Buskerud, in cooperation with Buskerud county. The intention is to publish the material online. Some early excavation reports are published in the open University of Oslo Research Archive, DUO, where they get a permanent link. KHM has also established a routine for publishing new reports at DUO.

The photo archives consist of artefact images, excavation and site documentation, as well as images from ethnographic fieldwork, documentation of exhibitions, and work and events at the university museums.

A substantial part of KHM's photo archive is digitised, and the files are stored in the national UniMus repository. This repository is for 2D documentation, as it also includes drawings. Today more than 500,000 of the objects are online.

\section{3D Documentation}

3D is used increasingly for documentation of artefacts and archaeological sites. Over several years KHM has 3D-documented the Viking Age ship collection with Structured Light Scanning (SLS), and, more recently, photogrammetry for both museum artefacts and archaeological field work and sites. The raw data and 3D models are stored at university servers. At an early stage, Sketchfab was chosen to make models available for the general public, and more than 200 rock art and other archaeological sites are uploaded. Today KHM uses the 3D HOP display system for publishing. More than 180 artefacts and more than 100 models from 30 archaeological sites are available at HumGIS portal.

KHM's BltFROST infrastructure project, aims to find the best solutions for storing these vast amounts of data and making them more accessible. BItFROST will address the question of use and active reuse of 3D models in research and education, and explore the possibilities of AR and VR. An important aspect of the project is a more developed user interface that allows the users to share collections, annotations and comments on each artefact. The models are published on the HumGIS portal.

\section{Availability}

The MUSIT data model is event based and builds on CIDOC CRM. The ADED data model is also based on CIDOC CRM, in order to facilitate wider sharing of data, as within ARIADNEplus. 
APIs and downloadable datasets are published online at Unimusportalen, which gives access to all the university museums' collections of archaeology, ethnography, and numismatics. Query results can be exported and reused, and images can be downloaded in high resolution and used under a CC-licence, most of them as CC BY-SA.

National archaeological data are also published by KHM at the HumGIS portal. This map-based interface, Arkeologiske undersøkelser (archaeological investigations), has an overview of all excavations in KHM's district, with some basic information and links to artefact catalogues, photo documentation, excavation reports, and Askeladden. Askeladden and the archaeological collections from all the university museums are also available as separate map layers.

The HER data in Askeladden is published without restrictions on the website. In addition, it can be found as a WMS and a dataset at the national website for map data and other georeferenced information from Geonorge.

\section{Further Development}

The long-lasting cooperation between the Norwegian university museums has made it possible to establish stable repositories, to publish online, and to link different sources. Still, the excavation documentation from the maritime museums are kept at separate repositories. Since all these excavation data mostly come from rescue excavations and collections management, it would be advantageous if they were accessible together with the data from the university museums.

Likewise, integration of research databases and data from individual researchers with the museum's collection data is still an outstanding issue. The Documentation Project in the 1990s focused on research databases, and we have kept this in mind as an ultimate goal for the common database solutions. An optimal solution would be to update the museum databases with recent research results. However, specialised research data often have formats that make it difficult to enter them into the general museum database. One obvious need is a system to tag research databases in a way that follows the FAIR principles. The recently started FAIR@UiO project at the University of Oslo addresses how to create sustainable repositories for research data adhering to the FAIR principles, and archaeological data should be included in these plans.

The infrastructure and repositories in Norway are financed by large institutions, and the databases are in constant use for site protection, research, and dissemination. In this way, it is a sustainable system. An important part of further development will be to include more material in the national database, and to reach out globally through international cooperation. 


\section{Bibliography}

Aukrust, K. and Hodne, B. (eds) 1998 Fra skuff til skjerm, Universitetsforlaget, Oslo.

Engevik jr., A., J. Holmen, Innselset, S. and Stabell, J. 2004 'Digital Archaeological Resources at the University of Bergen: an Efficient Tool in Research and Heritage Management?' in K. Fennema and H. Kamermans (eds) Making the connection to the Past. CAA 99 Computer Applications and Quantitative Methods in Archaeology. Proceedings of the 27th Conference, Dublin, April 1999, Leiden University, Leiden. 43-

47. https://proceedings.caaconference.org/files/1999/06 Engevik et al CAA 1999. pdf

Gustavsen, L. and Stamnes, A.A. 2014 'Archaeological Use of Geophysical Methods in Norwegian Cultural Heritage Management - a Review' in A.G. Posluschny, M. Gojda and $\mathrm{H}$. Kamermans (eds) A Sense of the Past. Studies in current archaeological applications of remote sensing and non-invasive prospection methods, BAR International Series 2588, Archaeopress, Oxford. 17-32.

Holmen, J. and Uleberg, E. 1996 'The National Documentation Project of Norwaythe Archaeological Sub-Project', Analecta Praehistorica Leidensia 28, 4346. https://proceedings.caaconference.org/paper/06 holmen uleberg caa 1995/

Kristensen, S. 2004 'Fra graving til data: den digitale dokumentasjonen av vikingtidsbyen Kaupang', Nicolay Arkeologisk Tidsskrift 93, 4-13.

Matsumoto, M. and Uleberg, E. 2015 'Digitizing archaeology in Norway' in K. Piotrowska and P. Konieczny (eds) CONDITION.2015 Conservation and digitalization, National Maritime Museum in Gdańsk, Gdańsk. 159-164. PDF

Ore, C.-E. and Rangsæter, O. 2007 Final report for the Museum Project 19982006. https://www.muspro.uio.no/final\%20report\%20museum\%20project.pdf

Ore, C.-E.S. and Uleberg, E. 2019 'The ADED project-a Norwegian infrastructure for excavation data' in F. Niccolucci and J. Richards (eds) The ARIADNE Impact, Archaeolingua, Budapest. 123-133. https://doi.org/10.5281/zenodo.3476712

Uleberg, E. and Matsumoto, M. 2010 'National extensive databases in Norwaypitfalls in a bright future' in B. Frischer, J.W. Crawford and D. Koller (eds) Making History Interactive. Computer Applications and Quantitative Methods in Archaeology (CAA). Proceedings of the 37th International Conference, Williamsburg, Virginia, United States of America, March 22-26, 2009, BAR International Series 2079, Archaeopress,

Oxford. http://archive.caaconference.org/2009/articles/Uleberg Contribution339 c\% 20(2).pdf

Uleberg, E. and Matsumoto, M. 2019 'Georeferencing museum collections' in M. Doerr, Ø. Eide, O. Grønvik and B. Kjelsvik (eds) Humanists and the digital toolbox. In honour of Christian-Emil Smith Ore, Novus forlag, Oslo. 111-134. 
